\title{
PENGARUH MODEL PEMBELAJARAN EKSPOSITORI BERBANTUAN SCAFFOLDING DAN ADVANCE ORGANIZER TERHADAP HASIL BELAJAR FISIKA PESERTA DIDIK KELAS X
}

\author{
Ahmad Saifi Hasbiyalloh, Ahmad Harjono, Ni Nyoman Sri Putu Verawati \\ Program Studi Pendidikan Fisika \\ FKIP, Universitas Mataram \\ Jalan Majapahit No. 62, Mataram \\ E-mail: iifsaifi@gmail.com
}

\begin{abstract}
This research aimed to examine the effect of expository learning model scaffolding assisted and advance organizer toward physics learning outcome the students of class $X$. This is a quasi experiment with pretest-postest control group design. The population of this research is all students of class X IPA SMAN 4 Mataram. The sampling technique used is purposive sampling. There are two samples taken that is sample as a class given treatment in the form of learning using scaffolding expository aided learning model (class $X$ IPA 1) and classes treated using expository learning model assisted advance organizer (class X IPA 2). The data of learning outcome is obtained by using the multiple-choice test of 25 questions. After hypothesis testing using statistical test ( $t$-test separated varian). The first hypothesis testing showed that $t_{\text {count }}>t_{\text {table }}$ which means that $H_{o 1}$ is rejected and $H_{a 1}$ is accepted. The second hypothesis testing showed that, $t_{\text {count }}>t_{\text {table }}$ which means that $H_{02}$ is rejected and $H_{a 2}$ is accepted. Based on the hypothesis test, it can be concluded that there is effect of expository learning model with scaffolding and advance organizer to the physics learning outcome of students.
\end{abstract}

Keywords: Expository learning, learning outcome, scaffolding, advanve organizer.

\section{PENDAHULUAN}

Ilmu Pengetahuan Alam (sains) merupakan ilmu-ilmu serumpun yang terdiri dari biologi, fisika, kimia, geologi, dan astronomi yang berupaya menjelaskan setiap fenomena yang terjadi di alam (Gunawan, 2015). Fisika sebagai salah satu cabang dari IPA yang mempelajari gejala-gejala alam dan peristiwa alam baik yang dapat dilihat maupun yang bersifat abstrak.

Berdasarkan hasil observasi proses pembelajaran fisika masih dengan menggunakan metode ceramah sehingga peserta didik sulit menerima atau menangkap materi pelajaran yang disampaikan. Sementara itu kebanyakan guru dalam mengajar masih tidak melakukan pembelajaran bermakna, model yang digunakan kurang bervariasi, sehingga cara belajar peserta didik cenderung menghafal. Peserta didik juga sering beranggapan bahwa pelajaran fisika sangat sulit dan membosankan karena banyak rumus- rumus yang harus dihafal dan dipahami, sehingga kenyataan yang dapat dilihat bahwa dalam hasil belajar fisika yang dicapai peserta didik masih rendah. Untuk mencapai hasil belajar fisika yang sangat memuaskan, peranan guru sangat diperlukan dalam penerapan model dan strategi belajar yang tepat. Sehingga dalam hal ini salah satu model pembelajaran yang coba diterapkan adalah model pembelajaran ekspositori.

Model pembelajaran ekspositori adalah model pembelajaran yang menekankan pada proses penyampaian materi secara verbal dari seorang guru kepada sekelompok peserta didik dengan maksud agar peserta didik dapat menguasai materi pembelajaran secara optimal. Keunggulan model pembelajaran ini adalah (a) dengan model pembelajaran ekspositori guru bisa mengontrol urutan dan keluasan materi pembelajaran, dengan demikian guru dapat mengetahui sampai sejauh mana peserta didik menguasai bahan 
pelajaran yang disampaikan, (b) model pembelajaran ekspositori dianggap sangat efektif apabila meteri pembelajaran yang harus dikuasai peserta didik cukup luas, sementara itu waktu yang dimiliki untuk belajar terbatas, (c) melalui model pembelajaran ekspositori selain peserta didik dapat mendengar melalui penuturan (kuliah) tentang suatu materi pelajaran, juga sekaligus peserta didik bisa melihat atau mengobservasi (melalui pelaksanaan demonstrasi), dan (d) model pembelajaran ini bisa digunakan untuk jumlah peserta didik dan ukuran kelas yang besar (Sanjaya, 2006). Selain itu, hal ini juga diperkuat dari hasil penelitian sebelumnya yaitu Atriyanto \& Sulistyo (2014) yang menyatakan bahwa hasil belajar peserta didik yang menggunakan strategi ekspositori lebih baik dibandingkan peserta didik yang menggunakan model pembelajaran konvensional.

Pembelajaran dengan model ekspositori akan menjadi lebih efektif apabila menggunakan strategi pembelajaran sebagai pendukung yaitu salah satunya adalah scaffolding. Istilah scaffolding digunakan pertama kali oleh Wood, Bruner \& Ross (1976), dengan pengertian yaitu merupakan dukungan pembelajar kepada peserta didik untuk membantunya menyelesaikan proses belajar yang tidak dapat diselesaikannya sendiri. Katminingsih dalam Septriani et. al. (2014) menyatakan bahwa scaffolding adalah memberikan kepada seorang anak, sejumlah besar bantuan selama tahap-tahap awal pembelajaran dan kemudian mengurangi bantuan tersebut dan memberikan kesempatan kepada anak tersebut mengambil alih tanggung jawab yang semakin besar segera setelah mampu mengerjakan sendiri, sehingga peserta didik tersebut dapat memecahkan masalahnya sendiri. Penelitian terkait scaffolding yaitu Rahmatiah et. al. (2016) yang menyatakan bahwa strategi scaffolding konseptual dalam pembelajaran Group Investigation dapat meningkatkan prestasi belajar fisika peserta didik.

Selain scaffolding, bantuan berupa advance organizer diduga dapat membantu peserta didik dalam belajar. Ausubel dalam Harjono (2012) menggambarkan bahwa advance organizer is information that presented prior to learning and can be used by the learner to organize and interpret new incoming information. Advance organizer adalah suatu informasi yang memiliki hubungan erat dengan apa yang akan dipelajari peserta didik. Advance organizer tidaklah berisi informasi yang sama dengan materi yang akan diajarkan oleh guru, tetapi justru mencakupnya secara umum dan merupakan perantara antara yang sudah diketahui dengan yang akan dipelajari (Rachmawati \& Daryanto, 2015). Penelitian terkait dengan advance organizer antara lain dilakukan oleh Nopiani et. al. (2017) menunjukan bahwa model pembelajaran advance organizer berbantuan peta konsep berpengaruh positif terhadap hasil belajar fisika peserta didik.

Penelitian lebih lanjut perlu dilakukan dengan menggunakan model pembelajaran ekspositori yang berbantuan scaffolding dan advance organizer. Peneliti merasa tertarik melakukan penelitian dengan judul pengaruh model pembelajaran ekspositori yang berbantuan scaffolding dan advance organizer terhadap hasil belajar peserta didik kelas X. Peneliti berharap penggunaan model pembelajaran ekspositori yang berbantuan scaffolding dan advance organizer ini mampu meningkatkan hasil belajar peserta didik pada pembelajaran fisika di tingkat sekolah menengah atas.

\section{METODE PENELITIAN}

Desain dari penelitian kuasi eksperimen ini menggunakan non-equivalent control group 
design with pre-test-and post-test. Suatu penelitian memiliki beberapa variabel penelitian sehingga pembaca dapat mengetahui alur dari sebuah eksperimen. Penelitian ini melibatkan variabel bebas yaitu model pembelajaran ekspositori, scaffolding dan advance organizer, variabel terikat yaitu hasil belajar fisika, dan variabel kontrol yaitu waktu, guru yang mengajar dan materi ajar.

Penelitian ini dilakukan di SMA Negeri 4 Mataram. Populasi penelitian adalah 4 kelas. Sampel penelitian adalah 68 peserta didik yang dibagi dalam dua kelas yaitu masing-masing 34 peserta didik untuk kedua kelas. Pemilihan sampel ditentukan dengan purposive sampling, dimana harus ada sebab khusus dalam pengambilan sampel. Sebab peneliti mengambil kelas X IPA 1 dan kelas X IPA 2 sebagai sampel adalah karena dari 4 kelas $\mathrm{X}$ pada sekolah tersebut, nilai rata-rata UTS kelas $\mathrm{X}$ IPA 1 dan kelas $\mathrm{X}$ IPA 2 memiliki perbedaan yang sangat tipis, secara berturutturut nilainya adalah 63,20 dan 63,25. Nilai tersebut kurang dari KKM yaitu 70,00.

Instrumen yang digunakan adalah tes pilihan ganda sebanyak 25 soal. Instrumen tes pilihan ganda sebelum digunakan harus memenuhi beberapa syarat yaitu uji validitas, reliabilitas, tingkat kesukaran soal dan daya beda. Uji statistik parametrik yang digunakan adalah uji-t Separated Varians dengan taraf signifikan 5\% dan harga $t$ tabel dihitung dari selisih harga $t$ tabel dengan $d k=n_{1}-1$ dan $d k=n_{2}-1$, dibagi dua dan kemudian ditambah dengan harga t yang terkecil.

\section{HASIL DAN PEMBAHASAN}

Penelitian ini bertujuan untuk mengetahui apakah ada pengaruh model pembelajaran ekspositori berbantuan scaffolding dan advance organizer terhadap hasil belajar fisika peserta didik kelas X. Penelitian dilakukan dengan memberikan perlakuan berupa penerapan model pembelajaran ekspositori berbantuan scaffolding pada kelas eksperimen 1 (X IPA 1) dan perlakuan berupa penerapan model pembelajaran ekspositori berbantuan advance organizer pada kelas eksperimen 2 (X IPA 2). Kedua kelas diberikan perlakuan selama empat kali pertemuan. Sebelum diberikan perlakuan kedua kelas diberikan tes awal yang bertujuan untuk mengetahui kemampuan awal peserta didik pada kedua kelas.

Penelitian ini sudah dilakukan kurang lebih satu bulan. Penelitian ini mengukur hasil belajar pada ranah kognitif yaitu $\mathrm{C} 1$ sampai C6 yang bertujuan untuk mengetahui pengaruh pembelajaran fisika menggunakan model pembelajaran ekspositori berbantuan scaffolding dan advance organizer terhadap hasil belajar fisika peserta didik kelas X. Data tentang hasil kemampuan peserta didik sebelum dan sesudah perlakuan diperoleh melalui tes awal dan tes akhir.

Kemampuan awal peserta didik baik kelas eksperimen 1 maupun kelas eksperimen 2 berdasarkan hasil tes awal masih rendah. Hal ini terlihat dari nilai rata-rata tes hasil belajar kelas eksperimen 1 dan kelas eksperimen 2 berturut-turut adalah 48,70 dan 48,11. Jika dibandingkan dengan nilai KKM, rata-rata tersebut dikategorikan tidak tuntas. Hal ini disebabkan karena kurangnya kemampuan peserta didik untuk menghubungkan pengetahuan yang lama dengan pengetahuan baru dan bagaimana mengkonstrusikan pengetahuan tersebut, sehingga solusi yang diterapkan oleh peneliti adalah melaksanakan pembelajaran menggunakan model ekspositori berbantuan scaffolding dan advance organizer. Pengambilan data untuk data kemampuan awal dan akhir dilakukan dengan memberikan tes, yaitu tes awal dan tes akhir. Tes hasil belajar yang digunakan adalah tes pilihan ganda yang terdiri dari 25 soal yang 
telah diuji validitas dan reliabilitasnya. Pada hasil uji coba instrumen terdapat 25 soal yang diterima dan terdapat 5 soal yang ditolak. Sehingga peneliti menyimpulkan untuk mengambil 25 soal tersebut untuk diberikan ke peserta didik pada saat melakukan tes awal dan tes akhir.

Hasil tes akhir menggambarkan bahwa hasil belajar peserta didik berbeda dengan hasil belajar awalnya. Kedua kelas eksperimen mengalami peningkatan. Peningkatan kelas eksperimen 2 lebih baik daripada peningkatan pada kelas eksperimen 1, namun perbedaan peningkatannya sangat kecil, sehingga dapat dikatakan bahwa model pembelajaran ekspositori berbantuan scaffolding dan advance organizer sama-sama berhasil meningkatkan hasil belajar fisika peserta didik dengan sangat baik. Terkandung lima sintaks dalam kegiatan pembelajaran, yaitu persiapan, penyajian, korelasi, menyimpulkan dan mengaplikasikan. Kelas eksperimen 1 mendapat bantuan LKPD scaffolding yang memberikan bantuan berupa jawaban yang menuntun peserta didik agar dapat menjawab soal alam LKPD sendiri, jawaban tersebut terus dikurangi sampai akhirnya peserta didik tersebut dapat menjawabnya sendiri. Pada kelas eksperimen 2 diberikan bantuan berupa advance organizer yaitu berupa peta konsep di awal pembelajaran, sehingga peserta didik dapat mengetahui mengenai gambaran dari materi yang akan diajarkan dalam setiap pertemuan. Kedua hal tersebut ternyata sangat efektif dalam meningkatkan hasil belajar fisika peserta didik.

Pengaruh dari perlakuan yang diberikan kepada kedua kelas eksperimen dapat diketahui dengan membandingkan kedua kelas eksperimen dengan satu kelas konvensional dan di uji menggunakan uji t. Sebelum melakukan uji-t, dilakukan terlebih dahulu uji normalitas dan uji homogenitas. Uji normalitas dilakukan bertujuan untuk memperoleh sampel yang berdistribusi normal dan uji homogenitas bertujuan untuk mengetahui apakah varians kelas eksperimen 1, kelas eksperimen 2 dan kelas konvensional.

Hasil tes menunjukkan adanya peningkatan yang signifikan pada tes akhir kelas eksperimen 1 yang menggunakan bantuan scaffolding. Pada hasil tes akhir diperoleh rata-rata kelas eksperimen 1 yaitu 75,12 . Nilai rata-rata dari tes awal dengan tes akhir sangat jauh berbeda yaitu dari 48,7 menjadi 75,12. Hal tersebut menunjukkan bahwa perlakuan yang diberikan pada kelas eksperimen 1 yang menggunakan bantuan scaffolding berdampak positif terhadap peningkatan hasil belajar peserta didik. Selain itu, pada hasil uji hipotesis pertama dengan membandingka hasil tes akhir pada kelas eksperimen 1 dengan kelas konvensional menggunakan uji-t (separated varian) diperoleh hasil $t_{\text {hitung }}=12,35$ sedangkan $t_{\text {tabel }}=1,99$. Hal ini menunjukkan bahwa $t_{\text {hitung }}$ lebih besar dari pada $t_{\text {tabel }}$ dengan demikian $\mathrm{H}_{01}$ ditolak dan $\mathrm{H}_{\mathrm{a} 1}$ diterima, artinya terdapat pengaruh penerapan model pembelajaran ekspositori berbantuan scaffolding terhadap hasil belajar fisika peserta didik, hal ini terjadi karena diberikan bantuan scaffolding peserta didik mendapatkan bantuan secara terus menerus dalam mengerjakan LKPD hingga mereka dapat menyelesaikannya sendiri LKPD yang diberikan. Hasil penelitian ini sejalan dengan penelitian sebelumnya, Apriana et. al. (2013) menyatakan bahwa terdapat pengaruh scaffolding dalam pemecahan masalah fisika berbasis multirepresentasi terhadap hasil belajar fisika peserta didik SMA.

Kelas eksperimen 2 setelah tes akhir memperoleh nilai rata-rata sebesar 75,53. Nilai rata-rata tersebut sangat berbeda dengan nilai pada tes awal yaitu 48,11. Berdasarkan nilai 
rata-rata tersebut menunjukkan bahwa ada peningkatan yang signifikan setelah kelas eksperimen 2 diberikan perlakuan berupa bantuan advance organizer, sehingga dapat diketahui bahwa advance organizer berpengaruh positif terhadap peningkatan hasil belajar fisika peserta didik. Selain itu, pada hasil uji hipotesis kedua dengan membandingka hasil tes akhir pada kelas eksperimen 2 dengan kelas konvensional menggunakan uji-t (separated varian) diperoleh $t_{\text {hitung }}=12,35$ sedangkan $t_{\text {tabel }}=$ 1,99714. Hal ini menunjukkan bahwa $t_{\text {hitung }}$ lebih besar dari pada $t_{\text {tabel }}$ dengan demikian $\mathrm{H}_{02}$ ditolak dan $\mathrm{H}_{\mathrm{a} 2}$ diterima, artinya terdapat pengaruh penerapan model pembelajaran ekspositori berbantuan advance organizer terhadap hasil belajar fisika peserta didik karena dengan adanya bantuan advance organizer peserta didik lebih mudah dalam menerima pelajaran sebab peserta didik telah mengetahui gambaran secara umum dari materi yang akan dijelaskan oleh guru sehingga terciptanya pembelajaran bermakna. Hasil penelitian ini sejalan dengan penelitian sebelumnya. Penelitian terkait dengan advance organizer antara lain dilakukan oleh Silaban \& Simanjuntak (2014) menyatakan bahwa model advance organizer dapat meningkatkan hasil belajar peserta didik.

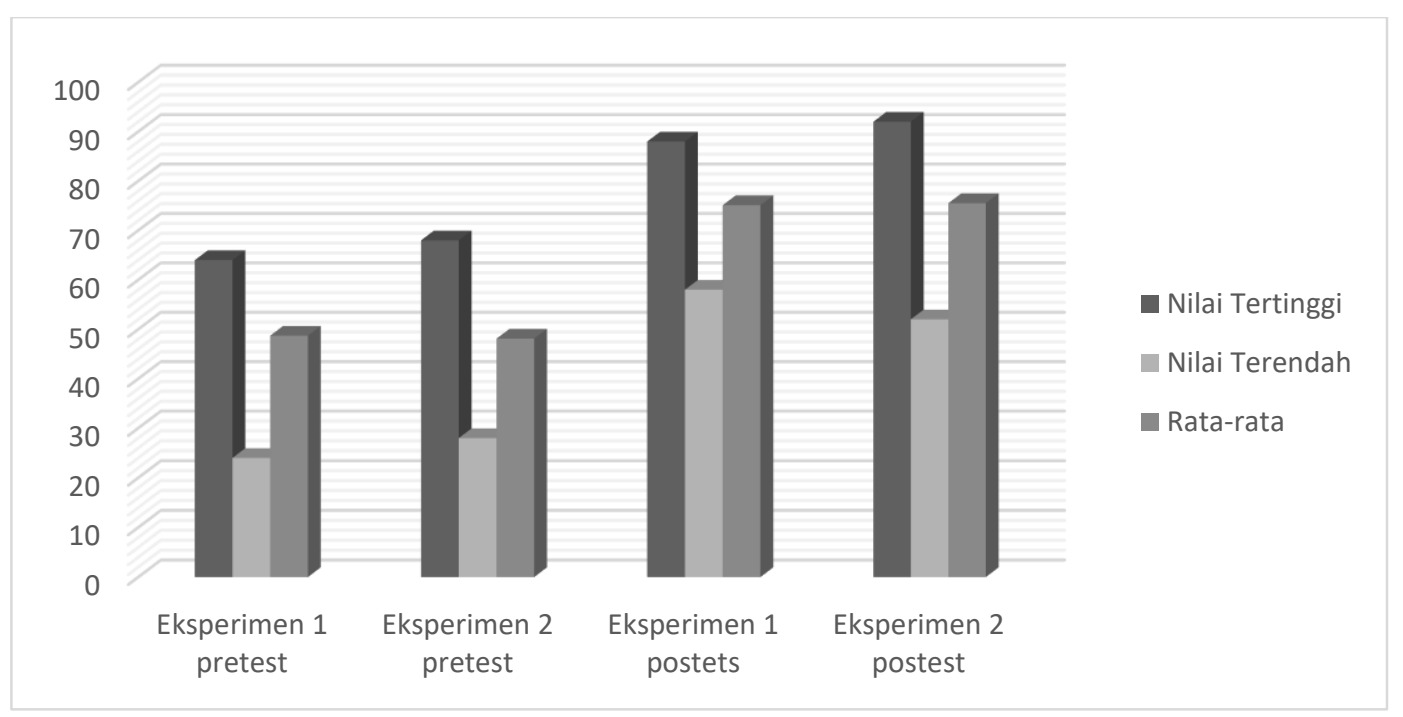

Gambar 1. Hasil Belajar Pada Kedua Kelas

Gambar 1. menunjukkan perbedaan nilai tertinggi, nilai terendah dan nilai rata-rata dari masing-masing kelas. Terlihat bahwa perbedaan antara nilai tertinggi dan nilai terendah antara kedua kelas tidak jauh berbeda. Rata-rata hasil belajar antara kedua kelas juga tidak berbeda secara signifikan.

Pembelajaran bermakna merupakan suatu proses mengaitkan informasi baru pada konsep-konsep relevan yang terdapat dalam struktur kognitif seseorang. Konsep ini menjelaskan bahwa dalam diri seorang pelajar sudah ada organisasi dan kejalasan tentang pengetahuan dibidang subjek tertentu. Organisasi yang dimaksud sebagai struktur kognitif dan percaya bahwa struktur ini menentukan kemampuan pelajar untuk menangani berbagai ide dan hubungan baru. Oleh karena itu, dengan diberikan bantuan advance organizer peserta didik melakukan belajar bermakna, karena dapat menghubungkan antara pengetahuan baru yang telah didapat, dengan pengetahuan lama, sesuai dengan teori Ausubel. Seperti yang 
dikatakan oleh Harjono (2012) bahwa advance organizer dapat membantu agar informasi lebih bermakna (meaningful) dengan menghubungkan pengetahuan sebelumnya dengan pengetahuan baru dan berfungsi sebagai intellectual scaffolding. Menurut Ausubel (1968) belajar dengan penemuan yang bermakna yaitu mengaitkan pengetahuan yang telah dimilikinya dengan materi pelajaran yang dipelajari itu. Atau sebaliknya, peserta didik terlebih dahulu menemukan pengetahuannya dari apa yang ia pelajari kemudian pengetahuan baru tersebut ia kaitkan dengan pengetahuan yang sudah ada.

Berdasarkan hasil tersebut dapat diketahui bahwa walaupun perlakuan yang diberikan pada kedua kelas tersebut berbeda, namun menunjukkan hasil yang relatif sama, yaitu sama-sama memberikan peningkatan yang positif pada hasil belajar peserta didik. Kelas eksperimen 2 yang diberikan perlakuan menggunakan bantuan advance organizer memiliki peningkatan yang lebih baik dibandingkan dengan kelas eksperimen 1 yang diberikan bantuan scaffolding meskipun mereka mendapatkan bantuan secara terus menerus hingga mereka dapat menyelesaikannya sendiri LKPD yang diberikan, hal tersebut terjadi karena pada kelas eksperimen 2 dengan adanya bantuan advance organizer peserta didik lebih mudah dalam menerima pelajaran sebab peserta didik telah mengetahui gambaran secara umum dari materi yang akan dijelaskan oleh guru. Meskipun demikian, perbedaan peningkatannya sangatlah tipis sehingga dapat diatakan bahwa tidak ada pebedaan yang signifikan dari hasil peningkatan hasil belajar pada kedua kelas eksperimen. sehingga baik scaffolding ataupun advance organizer memiliki dampak yang sangat positif dalam meningkatkan hasil belajar peserta didik. Oleh karena itu, hasil penelitian ini menunjukkan perbedaan peningkatan yang sangat tipis antara kedua kelas. Kedua perlakuan ternyata memiliki dampak yang sama baiknya sehingga tidak ada pengaruh yang signifikan dari kedua perlakuan tersebut.

Temuan dalam penelitian ini memperkuat temuan pada beberapa penelitian sebelumnya. Penelitian Harjono (2012) menunjukkan bahwa pemberian advance organizer dapat meningkatkan hasil belajar lebih tinggi dibandingkan tanpa pemberian advance organizer. Penelitian Hamdanillah et. al. (2017) menyatakan bahwa model pembelajaran advance organizer menggunakan video pembelajaran memberikan pengaruh yang positif dan signifikan terhadap hasil belajar fisika peserta didik. Penelitian Sungkawan \& Motlan (2013) menyatakan bahwa hasil belajar peserta didik yang diajarkan dengan menggunakan model pemebelajaran advance organizer berbasis eksperimen cendrung lebih baik dibandingkan dengan peserta didik yang diajarkan dengan model pembelajaran direct instruction. Penelitian Sinulingga \& Munte (2012) menyatakan bahwa hasil belajar peserta didik yang diajarkan menggunakan model pembeajaran advance organizer berbasis mind map lebih tinggi dari pada peserta didik yang diajarkan dengan menggunakan model pembelajaran konvensional. Penelitian Haryadi \& Achmadi (2013) menyatakan bahwa materi ajar berbasis scaffolding dapat meningkatkan tingkat pemahaman peserta didik secara signifikan. Penelitian Nabila et. al. (2016) menyatakan bahwa penerapan strategi scaffolding dapat meningkatkan ketuntasan hasil belajar peserta didik. Penelitian Septriani et. al. (2014) menyatakan bahwa pemahaman konsep matematis peserta didik yang belajar dengan scaffolding lebih baik dari pada peserta didik yang belajar dengan menggunakan pembelajaran 
konvensional. Temuan-temuan para peneliti tersebut membuktikan bahwa pemberian advance organizer maupun scaffolding berdampak positip terhadap peningkatan hasil belajar peserta didik.

Hasil penelitian ini menunjukkan model pembelajaran ekspositori berbantuan scaffolding dan model pembelajaran ekspositori berbantuan advance organizer berpengaruh positif terhadap peningkatan hasil belajar peserta didik dan telah sesuai dengan teori yang telah dijabarkan sebelumnya. Oleh karena itu, dapat dikatakan bahwa perlakuan pada penelitian ini dapat meningkatkan hasil belajar fisika peserta didik sejalan dengan penelitian-penelitian sebelumnya.

\section{PENUTUP}

Berdasarkan uji hipotesis, dapat disimpulkan bahwa ada pengaruh penerapan model pembelajaran ekspositori berbantuan scaffolding dan penerapan model pembelajaran ekspositori berbantuan advance organizer terhadap peningkatan hasil belajar peserta didik SMAN 4 Mataram kelas X IPA 1 dan X IPA 2. Adapun saran yang dapat diberikan yaitu hasil penelitian ini dapat digunakan oleh guru untuk membantu meningkatkan hasil belajar fisika peserta didik di sekolah.

\section{REFERENSI}

Atriyanto, B \& Sulistyo, E. 2014. Pengaruh Strategi Pembelajaran Ekspositori Terhadap Hasil Belajar Peserta didik pada Mata Diklat Memperbaiki Compact Cassete Recorder Kelas XI TAV di Sma Negeri 2 Surabaya. Jurnal Pendidikan Teknik Elektro. 3(2), 09-13.

Ausubel, D.P. 1968. Educational Psychology: A Cognitive View. New York: Holt, Rinehart, and Winston.
Gunawan. 2015. Model Pembelajaran Sains Berbasis ICT. Mataram: FKIP UNRAM.

Hamdanillah, N., Harjono, A., \& Susilawati. 2017. Pengaruh Model Pembelajaran Advance Organizer Menggunakan Video Pembelajaran Terhadap Hasil Belajar Fisika Peserta Didik Kelas X. Jurnal Pendidikan Fisika dan Teknologi. 3(2), 119-127.

Harjono, A. 2012. Perbedaan Strategi Pembelajaran dan Pemberian Advance Organizer Pengaruhnya Terhadap Hasil Belajar Fisika Peserta didik Kelas X. Jurnal Pijar MIPA. 7(1), 13-17.

Haryadi, A. \& Achmadi, H.R. 2013. Pengembangan Materi Ajar Berbasis Scaffolding pada Pokok Bahasan Analisis Vektor di SMAN 1 Waru Pamakasan. Jurnal Inovasi Pendidikan Fisika. 2(3), 174-179.

Luritawaty, Irena P., \& Nuraeni, R. 2015. Model Advance Organizer dalam Pembelajaran Matematika untuk Meningkatkan Kemampuan Pemecahan Masalah Matematis Siswa. Jurnal Pendidikan Matematika. 6 (1), 13-19.

Nabila, F.M., Gani, A., \& Habibati. 2016. Pengaruh Penerapan Strategi Scaffolding Terhadap Ketuntasan Belajar Peserta Didik SMA Negeri 4 Banda Aceh Pada Sub Materi Tata Nama Senyawa Hidrokarbon. Jurnal Ilmiah Mahasiswa Pendidikan Kimia. 2(2), 127-135.

Nopiani, R., Harjono, A., \& Hikmawati. 2017 Pegaruh Model Pembelajaran Advance Organizer Berbantuan Peta Konsep Terhadap Hasil Belajar Fisika Siswa SMA Negeri 1 Lingsar. Jurnal Pendidikan Fisika dan Teknologi. 3(2), 137-145.

Rahmatiah, R., \& Kusairi, S. (2017). Pengaruh Scaffolding Konseptual dalam 
Pembelajaran Group Investigation Terhadap Prestasi Belajar Fisika Siswa SMA dengan Pengetahuan Awal Berbeda. Jurnal Pendidikan Fisika dan Teknologi. 2(2), 45-54.

Rusminingsih, P. 2015. Penerapan Metode

Ekspositori Untuk Meningkatkan

Prestasi Belajar Bahasa Inggris.

Kolaborasi. 1(9), 877-885.

Sanjaya, W. 2006. Strategi Pembelajaran Berorientasi Standar Proses Pendidikan. Jakarta: Kencana Prenadamesia Grup.

Septriani, N., Irwan \& Meira. 2014. Pengaruh Pendekatan Scaffolding terhadap Kemampuan Pemahaman Konsep Matematika Peserta didik Kelas VIII SMP Pertiwi 2 Padang. Jurnal Pendidikan Matematika. 3(3), 17-21.

Sinulingga, K, \& Munte, D. 2012. Pengaruh Model Pembelajaran Advance Organizer Berbasis Mind Map Terhadap Hasil Belajar Fisika Peserta didik Pada Materi Pokok Besaran dan Satuan di Kelas X SMA. Jurnal Pendidikan Fisika. 1(2), 16.

Sungkawan, R, \& Motlan. 2013. Analisis Penguasaan Konsep Awal Fisika Pada Pembelajaran Menggunakan Model Advance Organizer Berbasis Eksperimen Terhadap Hasal Belajar Fisika. Jurnal Pendidikan Fisika. 2(2), 73-80. 